\title{
12 Eylül 1980 ve 28 Şubat 1997 Askeri Darbe Dönemlerinde TÜSIAD-Devlet íliş̧kisi
}

\author{
Eyüp Bayram Şekerli" \& Eyüp Akçetin**
}

Öz

Örgütler çevreden etkilendikleri gibi çevre üzerinde çeşitli şekillerde etkili olabilmektedirler. Bu şekillerden birisi de bir araya gelerek oluşturdukları sivil toplum kuruluşlarıdır. 1971 yılında kurulan TÜSIAD, Batıya entegre ve liberal bir ekonomik yapı oluşturma konusunda hükümetlerin politikalarını etkilemeye çalışmışıı. 1980'li yılların başında ekonomik olarak daha güçlü hale gelen TÜSiAD'ın devlet ile olan ilişkisinde de çeşitli değişimler olmuştur. Bu çalışmada iş adamlarının devletin ekonomik politikalarını etkilemek için oluşturdukları örgütlenmenin kamu politikası programlarındaki değişimi anlamak için Türkiye'de ekonomik ve siyasi belirsizliklerin yaşandığı 12 Eylül 1980 ve 28 Şubat 1997 askeri darbe süreçleri vaka olarak alınarak incelenmiştir. TÜSiAD'ın devlet ile olan ilişkisinde serbest, dış ticarete dönük ve batıyla bütünleşmiş bir ekonomik yapı oluşturma girişimleri raporlar, bültenler ve gazete haberlerinin içerikleri incelenerek ortaya konulmaya çalışılmıştır. Bu kapsamda, TÜSiAD'ın 1980'li yıllarda devlete sadece liberal ekonomik politikaları benimsetme ve uygulatma konusunda çalışırken 1990'lı yıllara gelindiğinde ekonomi ile birlikte sosyopolitik konularda da baskı yapan bir güç haline geldiği görülmüştür.

Anahtar Kelimeler: TÜSIAD, Darbe, iş̧ Adamları Dernekleri.

TUSIAD-State Relations in the Periods of Military Coups of 12 September 1980 and 28 February 1997

\section{Abstract}

Organizations can be influenced by the environment as well as they influence their environment in various ways. One of these forms is to establish non-governmental organizations (NGOs) that support their intentions. TÜSIAD is established in 1971 and tried to influence the policies of the governments in order to realize a liberal economic structure that is integrated with the Western World. After becoming economically stronger in the 1980s, there have been various changes in the relationship between TÜSIAD and the state. In this study military coups realized on September 12, 1980 and February 28,1997 , whose before and aftermath are defined as periods of economic and political uncertainities, are taken as cases in order to understand TUSIAD's change in public policy programs. The relation between TÜSIAD and state, which is basically focused on promoting free economy, foreign trade, and an economic structure integrated with the Western World, is tried to be depicted by examining the content of reports, bulletins, and newspaper coverage. Consequently, it is observed that as TÜSIAD became economically stronger in the 1980s, it mostly urged the state to adopt and enforce liberal economic policies. In the 1990s, it is seen that TUSIAD became a force that pressures on sociopolitical issues along with the economical matters.

Keywords: TÜSIAD, Coup, Businessmen Associations.

*Dr. Öğr. Üyesi | Muğla Sıtkı Koçman Üni., Seydikemer Uygulamalı Bilimler Yüksekokulu eyupbs@mu.edu.tr | ORCID: 0000-0003-1562-4716 | DOI: 10.36484/liberal.739596

"Doç. Dr. | Muğla Sıtkı Koçman Üni., Seydikemer Uygulamalı Bilimler Yüksekokulu

eyup.akcetin@mu.edu.tr | ORCID: 0000-0001-7232-2154 | DOI: 10.36484/liberal.739596 Liberal Düşünce Dergisi, Yıl: 25, Sayı: 100, Güz 2020, ss. 115-135. Gönderim Tarihi: 19 Mayıs 2020 | Kabul Tarihi: 29 Aralık 2020 


\section{Giriş}

İş adamlarının oluşturduğu birlikler devlet ile olan ilişkilerinde bir koordinasyon sağlamaktadır. Firmaların başarılarında işletme-devlet ilişkileri bir etken olarak değerlendirilmektedir. Buğra (2013: 242), firmanın ve faaliyet alanının büyümesinin sadece piyasaya dayanarak açıklamanın mümkün olmadığını, özel sektör faaliyetlerinin sınırlarının belirlenmesinde devletin de önemli ölçüde söz sahibi olduğunu belirtmektedir. Buna göre, temel olarak üyelerinin faaliyet alanını geliştirmeye yönelmiş TÜSİAD'ın bunu yapabilmek için devlet ile ilişkisinde hangi tutumları sergilediğini ve bu tutumların zamanla nasıl değiştiğini anlamak önemlidir.

Türkiye'de 1971 yılından önce uygulanan planlı ekonomi ile yatırım mallarının kamu ve özel sektörle birlikte üretimini öngören bir yapı oluşturulmuştur. Bu ekonomik anlayış kapsamında ithal ikameci bir yaklaşımla yatırım mallarına ara mallardan daha fazla öncelik verilmesi nedeniyle bir süre sonra ithalat gereğinden fazla artmıştır. 1971 yılına gelindiğinde enflasyon iki haneli rakamlara çıkmış ve 1963-1967 yılları arasında 189 milyon dolar olan ortalama cari açık 1971 yılında 412 milyon dolara ulaşmıştır. Enerji bağımlılığı ve yaşanan petrol krizi nedeniyle dış ticaret açığı 1970'li yıllar boyunca artmaya devam etmiştir. Bu ekonomik koşullarda TÜSİAD, 1971 yılında bir sivil toplum örgütü olarak kurulmuştur. TÜSİAD, Türkiye'nin önde gelen girişimcilerinin ve iş dünyası yöneticilerinin oluşturduğu gönüllü bir iş dünyası kuruluşudur. Günümüzde TÜSİAD, Türk sermayesinin dörtte birine yakınını oluşturan şirketleri temsil etmektedir. Dış ticaretin \%85’ini gerçekleştiren TÜSİAD, kayıtlı istihdamın \%50'sini sağlamaktadır. TÜSİAD üyeleri ayrıca kurumlar vergisinin \%80'ini ödemektedir (http://tusiad.org/tr/ tusiad/hakkinda, erişim tarihi: 26.08.2017). Üyeliğe kabul politikası nedeni ile TÜSİAD, daha çok bir elit işadamları grubu olarak tanımlanmaktadır. TÜSİAD üyeleri Türkiye'nin daha çok batısında faaliyet gösteren iş adamlarıdır (Kluge, 2009:343). 2 Nisan 1971 tarihinde kurucular protokolünü; Vehbi Koç, Nejat Eczacıbaşı, Sakıp Sabancı, Selçuk Yaşar, Raşit Özsaruhan (METAŞ), Ahmet Sapmaz (Güney Sanayi), Feyyaz Berker, Melih Özakat (BMC), İbrahim Bodur (Çanakkale Seramik), Hikmet Erenyol, Osman Boyner ve Muzaffer Gazioğlu imzalamıştır. TÜSİAD, kısa sürede güçlü hale gelmiş, hükümete isteklerini kolaylıkla "dikte" ettirmeye varan bir siyasi etkinlikle siyasi ve ekonomik yaşama yön veren bir odak olmuştur (Sönmez, 1992:150-152).

TÜSİAD'ın devlet ile olan ilişkisinde üyeleri için uygun bir iş ortamının yaratmayı hedeflemesi doğal bir amaçtır. TÜSİAD; dönem dönem yayınladığı raporlar, yurtiçi ve yurtdışındaki ekonomik ve siyasi kuruluşların temsilcileri 
ile yaptıkları görüşmeler ile özellikle 1980'li yıllardan itibaren, siyasi bir baskı unsuru olarak ortaya çıkmıştır. TÜSİAD, kurulduğu günden itibaren ülke ekonomisini değerlendiren, ekonomik problemlere çözüm önerilerini içeren raporlar ve bültenler (Görüş Dergisi) oluşturmuştur. Bu yayınlardan ayrı olarak TÜSİAD yetkililerinin çeşitli platformlarda yaptıkları açıklamaları ve siyasiler ile kamuoyuna yansıyan görüşmeleri olmuştur. Bu kaynaklar çalışma kapsamında değerlendirilerek TÜSİAD’ın özellikle 12 Eylül 1980 ve 28 Şubat 1997 askeri müdahaleleri dönemlerindeki tutumlarının ortaya konulmasının iş gruplarının devlet ile olan ilişkilerinin anlaşılmasında farklı bir bakış açısı sağlayacağı düşünülmektedir. Diğer bir deyişle, firmaları temsil eden bir kuruluşun piyasa işleyişinin dışındaki davranışlarını anlayabilmek çalışmanın temel odağını oluşturmaktadır. Çalışma kapsamında ilgili literatür, tutanaklar, TÜSİAD raporları ve dönemin gazete haberleri taranarak TÜSİAD'ın darbe öncesinde ve sonrasındaki tutumları anlaşılmaya çalışılacaktır. Bu kapsamda 12 Eylül 1980 ve 27 Şubat 1997 askeri darbe döneminde TÜSİAD’ın gerek kurumsal olarak gerekse üyeleri tarafından yapılmış bireysel açıklamaları değerlendirilecektir. Araştırmada darbe dönemlerinin ele alınması TÜSİAD’ın darbe konusundaki tutumlarını anlamaktan çok bahsi geçen dönemlerin Türkiye'nin siyasi olduğu kadar ekonomik yönünü bulmaya çalıştığı dönemler olmasıdır.

\section{12 Eylül 1980 Askeri Müdahalesi Sürecinde TÜSIAD’ın Tutumu}

TÜSİAD, özel sektörün 1970-1980'li yıllarda önemli bir güç olmaya başlamasının bir sonucu olarak ortaya çıkmıştır. Özel sektör, 1980’lerin başında sanayide önemli bir güce erişmiştir, büyük firmalar da oldukça yetkin örgütlenme yapıları kurmuşlardır. Ayrıca, söz konusu dönemde büyük işadamlarının toplumsal konumlarında da bir gelişme gözlemlenmektedir. Büyük işadamlarının giderek kısa dönemde çıkarlarını etkileyen gelişmelerden çok uzun dönemli ekonomik stratejilerin oluşturulmasına önem vermeye başladıkları ve kamu politikalarının belirlenmesinde etkin olarak yer almak istedikleri gözlenmektedir. Ayrıca, büyük iş çevrelerinin 1960'lardan başlayarak kendilerini özel sektörün diğer kesimlerinin de içinde olduğu kuruluşlardan uzaklaştırdıkları izlenmekteydi. Buna bağlı olarak, büyük iş çevrelerinin talepleri giderek hükümete eskiden olduğu gibi odalar aracılığıyla değil önde gelen işadamları tarafından kişisel görüşmeler yoluyla aktarılıyordu. 1980'li yıllarda, özellikle Ömer Dinçkök'ün başkanlığıyla başlayan dönemde, hükümet ile dernek arasındaki sürtüşmeler önem kazanmıştır (Buğra, 2013: 338,339). 
Askeri darbeler, demokratik yolları devre dışı bırakarak toplumsal hayatta birtakım değişiklikler yapmak amacıyla gerçekleştirilmektedir. Darbeler ile ekonomi politikalarında değişikliklere gidilmektedir. Hatta askeri darbelerin ekonomik nedenleri olduğuna dair görüşler de ileri sürülmektedir. 1980 askeri darbesi ülkedeki terörün bitirilmesi için yapılmıştır fakat bir takım ekonomik düzenlemeler de darbenin peşi sıra gelmiştir. TÜSİAD’ın kurulduğu 1970'lerde dünyada Bretton Woods sisteminin çökmesi ile ABD’nin liberalizmi tüm dünyaya yayma çabası ağırlık kazanmıştır. IMF ve Dünya Bankası'nın da etkileri ile ülkelerin liberal ekonomik sistemi benimsemeleri istenmiştir. TUSİAD'ın bu konudaki destekleyici tutumunu 1970'li yılların sonunda dönemin Ecevit Hükümeti’nin ekonomi politikalarını eleştiren tavrında görmek mümkündür. TÜSİAD serbest ekonomiye geçiş ve ihracat ağırlıklı bir ekonomi anlayışının benimsenmesi konusunda Ecevit Hükümeti'nin yetersiz kaldığını düşünmektedir. Buğra (2013: 204, 206)'ya göre; Ecevit Hükümeti'nin IMF’nin önerdiği istikrar politikasını uygulama konusunda isteksizliği, sermaye malı ithalatında özel kesimin kullandığı kredilere kur garantisinin kaldırılması gibi konuların TÜSİAD'ın kısa süre içerisinde Ecevit Hükümetinin karşısında yer almasına neden olmuş ve CHP'nin yerel seçimlerdeki yenilgisini takiben dernek 1979 yılında hükümetin düşmesinde kısmi de olsa bir rol oynayacak yoğun kamuoyu oluşturma kampanyası başlatmıştır. Bu kapsamda TÜSİAD, yazılı basında hükümetin ekonomi konusundaki tutumunu eleştiren ilanlar vermiştir. 1979 yılında verilen bu ilanlarda ülkeyi refaha götürecek temel gücün hür teşebbüs olduğu vurgulanmakta, hür teşebbüsü olumsuz etkileyen enflasyonist ekonomi, vergi politikaları, yanlış kapsamlı ve verimsiz kamu yatırımları (özellikle KİT'lere yapılan yatırımlar) eleştirilmektedir. İlanlar kapsamında yasakçı ve devletçi zihniyetin ülkedeki refah sorununun temeli olarak ifade edilmektedir. TÜSİAD verdiği ilanlarda aynı zamanda "ekonomiyi yönetenlere" çözüm önerileri de vermiştir (Şekil 1). Bu ilanlarda, TÜSİAD’ın liberal ekonomi politikalarına geçiş konusunda hükümete baskı yapmaya çalıştığı görülmektedir. 
Şekil 1. TÜSİAD Tarafından 1979 Yılında Verilen “Gerçekçi Çıkış Yolu” ve "Ulus Bekliyor" İlanları

\section{Ulus Bekliyor}

Ne bekler hayattan bir ulusun fertleri?

Önce iş bekler. Çalışmak, kazanmak ister.

Her alanda tercihini serbestçe yapabilmek ister.

Tek iş kapısı olarak

karşısında yalnız devleti bulmanın

çaresizliğine düşmemek ister.

Hürriyet içinde örgütlenmek,

sendikasını seçmek ister.

Alın teriyle kazandığı paranın

ihtiyaçlarını karşılamasını ister.

Tasarruflarının değer kaybetmeyerek

yarınlarını güvenliğe almasını ister.

Yuva kurmak, çocuk yetiştirmek, mal edinmek, seyahat etmek, tüketmek ister.

Hürriyet içinde seçmek, seçilmek ister.

Kendisi ve yakınları için insanca bir hayat ister.

Korkusuz yaşamak ister.

Birlik, beraberlik, barış ister...

Oysa, bugün, milletimiz

bütün bu insanca yaşama şartlarının

tehdit altına girdiğini görmenin

ıstırabı içindedir.

Kısa vadeli politik kaygıların

hâlâ milli menfaatlerimizden

üstün tutulduğunu görmenin

hayal kırıklığı içindedir.
Çözüm,

ekonomimizi bir yasakçı mevzuat ağı içinde boğan,kişinin teşebbüs şevkini kıran,kişiyi yanlış yönlere sevk eden aşırı müdahaleci ve güven sarsıcı zihniyeti terk etmektedir.

Çözüm,

şiddetle ihtiyaç duyduğumuz

“dış para”yı, sadece siyasi ilişkilerde değil doğru ekonomik politikaları uygulama becerisinde aramak,sanayimizin çarklarını döndürmek,KİT'leri verimli çalışır düzeye eriştirecek cesur adımları almaktadır.

Çözüm,

Türk ekonomisinin dişa açılması, serbest rekabete dayalı Batı ekonomisi içinde gelişmesini hızlandıracak kararları alabilmektedir.

Ve çözüm,

ülkemizin ekonomik menfaatlerini kısa vadeli politik kaygılardan artık üstün tutmaktadır. 


\section{Gerçekçi çıkış yolu}

Nüfusumuz 44 milyonu aşmıştır.

Ylllık artış 1 milyon kişinin üzerindedir.

İşsiz sayısının geçen yıl 2 milyon 240 bin kişi olduğu ifade edilen ülkemizde, çalışabilir her 100 kişiden 14'ü işsizdir.

Oysa, uygulanan ekonomi politikaları ve sendikaların davranışları, Türkiye'de, işsizlik sorununu giderek daha da ağırlaştırmaktadır.

Ve.. bir yerde \%60'ı aşan korkunç enflasyon sosyal ve ekonomik bünyemizi kemirmeye devam etmektedir.

Türkiye nereye gidiyor?

Bir ülkede ekonomik bunalım neden doğar? Sorumluluk kimdedir?

Dünyanın sengin ülkeleri arasında girebilecek potansiyele sahip yurdumuz neden yoklar içine girmiştir?

Demokratik toplumumuzun üreten

- verimli üreten - temel gücünün

hür teşebbüs olduğunu artık anlamalıyız.

Ekonomimizi bir yasakçı "mevzuat ağı”

içinde boğan, kişinin teşebbüs şevkini kıran,

kişiyi yanlış yönlere sevk eden

aşırı müdahaleci ve güven sarsıcı zihniyet

bunalımın asıl sebebidir.

Daha çok çalışmanın, daha çok

üretmenin ve bolluğa kavuşmanın

gerçekçi yolu: “Kişiyi rekabet içinde teşvik”tir.

Zorlayıcı, önleyici önlemlerle üretim artmaz.

Olsa olsa ekonomik yapı çarpılır.

Giderek rejim değişir.

Hür teşebbüsün zayıflaması

hürriyetçi demokrasinin zayıflamasıdır.

Hür teşebbüsün yok olması ise, politik, ekonomik, sendikal, düşünsel, bütün hürriyetlerle birlikte, hürriyetçi demokrasinin de yok olmasıdır.
Şiddetle ihtiyaç duyduğumuz diş kredilerle, uyguladığımız ekonomik sistem birbirine çok yakından bağlıdır. Pazar ekonomisinden gitgide uzaklaşan bir anlayışla, ne Batı dünyasında hak ettiğimiz yeri, ne yeterli kredileri, ne de yatırımlara gerekli dış sermayeyi bulabiliriz.

Kaynak: (TUSİAD, 1979 Gazete İlanları, 1979) 
TÜSİAD tarafından ilanlar ile ilgili yapılan açıklamalarda siyasal bir amaç güdülmediği ifade edilse de (Milliyet Gazetesi, Berker: "Bildirimizin siyasal bir amacı yok”, 16.05.1979) verilen ilanlar dönemin hükümetin çeşitli organlarından tepki ile karşılanmıştır. Koyuncu (2006:130), TÜSİAD’ın bu eylemini Ecevit'in “iş adamları paralı muhtıra vermiştir” şeklinde açıkladığını belirtmektedir. Bu süreçte kurumsal olarak iletilen mesajların yanı sıra bazı üyelerin de siyasi ve ekonomi politikası odaklı açıklamalar yapmaktadırlar. Kamuoyuna yansıyan açıklamalarda daha sonra 24 Ocak Kararları ile kabul edilecek olan ve dış ticaret üzerinde olumlu etkiler yaratacağı öngörülen dalgalı kur sistemine geçiş gibi serbestleşmeye yönelik düzenlemeleri üyelerin talep ettikleri görülmektedir (Milliyet Gazetesi, “Berker”, 1979).

Şekil 2. Devlet-TÜSİAD Gerilimine Dair Gazete Haberleri

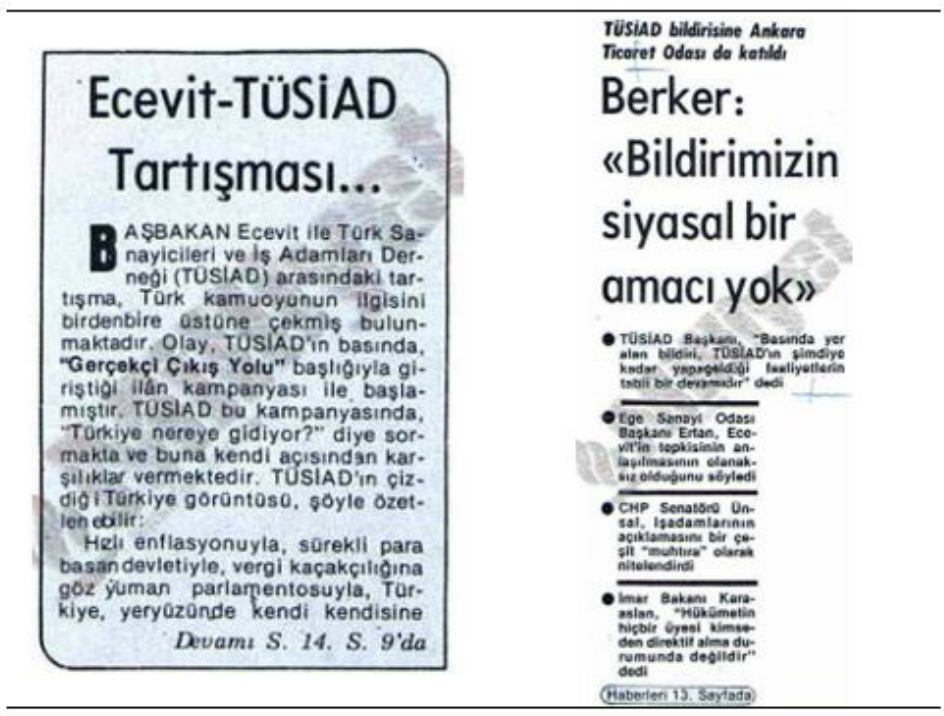

Kaynak: (Milliyet Gazetesi, Berker Borçtan kurtulmak için, 1979).

12 Eylül Askeri darbesinin ardından özellikle hükümetin ekonomi yönetimi ile ilgili yaptığı atamalar da TÜSİAD’ı memnun edecek yönde olmuştur. 1980 darbesi ile birlikte ithal ikameci politika yerine çok hızlı bir biçimde liberal anlayışı benimsemiş, Türkiye ekonomisi çok hızlı bir biçimde serbestleştirilerek dışa açılmıştır (Tatlıyer, 2017:2). 1980 darbesine gidiş sürecinde Türkiye'de liberal bir ekonomiye geçişi ifade eden 24 Ocak Kararları ile ithal ikameci politikalardan terkedileceği belirtilmiştir (Kalem, 2015:42). 24 Ocak 1980'de ihracata yönelik, kamusal ekonominin küçültülmesine odaklı bir istikrar programının daha iyi uygulanması askeri müdahale ile daha mümkün 
hale gelmiştir (Cumhuriyet Gazetesi, "12 Eylül Askeri Harekâtı Olmasaydı”, 1982). Koyuncu (2006:130), TÜSİAD’ın, 24 Ocak Kararları’nı ve 12 Eylül 1980 darbesi ile ilgili olumlu tutumlarına değinmektedir.

Darbenin ardından yeni hükümetin atama süreçlerinde de bazı TÜSİAD üyelerinin etkili olmaya çalıştıkları görülmektedir. Sermaye kesimine yakınlığı ile bilinen, Demirel Döneminde de ekonomi yönetiminde Başbakanlık Müsteşarı olarak görev almış olan Turgut Özal 12 Eylül Askeri Darbesinin ardından Bülent Ulusu hükümetinde Ekonomiden Sorumlu Başbakan Yardımcısı olmuştur. 24 Ocak Kararlarının da mimarı olan Turgut Özal'ın yeni hükümette görev alması iş çevreleri tarafından desteklenmiş ve yapılan atama memnuniyet ile karşılanmıştır. Nitekim, Vehbi Koç’un 1980 yılında Cumhurbaşkanı Kenan Evren'e yazmış olduğu mektupta Turgut Özal'ın yeni hükümette görev alması yönünde olumlu görüşler bildirilmektedir (Sönmez, 1992: 346). En nihayetinde 24 Ocak Kararları ile başlayan ve Turgut Özal'ın başbakan olması ile hızlanan Türk ekonomisi özelleştirmeye ve yabancı yatırıma açılmıştır. Böylece, özel sektörün ölçeğini genişletme konusunda adımlar atılmış ve özel kesimin kendine güveni artmıştır (Kluge, 2009:343). Başka bir deyişle, TUSİAD için arzu edilen şartların gerçekleşmesi yönünde adımlar atılmaya başlanmıştır. Nitekim,12 Eylül'e bir hafta kala yeni bir ekonomik rapor yayınlayan TÜSİAD’ın bu raporundaki talepler 12 Eylül Hükümet'ince büyük ölçüde karşılanmıştır (Sönmez, 1992:152). İlgili raporun ele aldığı en önemli problem ülkenin dışa açılamamasıdır. 1980 yılının başına kadar uygulanan dört istikrar paketinin (1977-Demirel Hükümeti Enflasyona Karşı Savaş Paketi; 1978-Ecevit Hükümeti “Yapısal Değişim” Paketi; 1978-Ecevit Hükümeti “Para Kredi Tedbirleri” Paketi; 1979-Ecevit Hükümeti “Ekonomiyi Kurtarma” Paketi) döviz rezervi problemleri, azalan kamu yatırımları nedeniyle yapılamayan alt yapı projeleri, özel kesim yatırımlarının enflasyon nedeniyle azalması ve yön değiştirmesi, istihdam ve KİT’ler ile ilgili problemlerini çözemediğini belirtilmektedir (Düzgün, 2019). TÜSİAD’a göre böyle bir ortamda çözüm dışa açılmak, ihracatı arttırmaktır. İhracatın karlılığı ise "kamu sorumlularının" elindedir. Diğer bir deyişle böyle bir karlılığı ancak hükümet sağlayabilir (TÜSİAD, 1980:4).

Görüldüğü üzere darbe ile yaşanan ekonomik geçiş sermaye kesiminin, siyasal geçiş ise iktidar bloğunu yeniden yapılandırmıştır. 1980 öncesinde yerli sermayenin belirli kesimleri yabancı sermaye ile işbirliği halinde sanayi girişimlerine dönüşürken, hem devlet hem de uluslararası sermaye örgütleri bu çabayı aktif bir biçimde desteklemiştir (Durmuş, 2011:107). Nitekim, 1980 yılı itibariyle kamu sektörü giderek küçülmeye başlamıştır. Özellikle 1984 yılından itibaren 2983 sayılı kanun ve 233 sayılı Kamu İktisadi Teşebbüsleri 
Hakkında Kanun Hükmünde Kararname (mad.38) ile KİT’lerin özelleştirilmesine başlanmış, özel sektörün GSYH içindeki payı giderek artmıştır (Kalem, 2015:46). Böylece, özel sektörü temsil eden TÜSİAD’ın bir yandan ekonomik gücü artarken siyasi alanda da daha fazla rol üstlenmeye başlamıştır (Kluge, 2009:343). Ayrıca, TÜSİAD’ın IMF ekonomi politikalarına uyulması ile ilgili anlayışına paralel adımlar 1980 askeri müdahalesinin ardından atılmaya başlanmıştır. Buğra (2013:206)'ya göre nihayet 1980 askeri darbesi ile aynı zamanda IMF politikalarının uygulanmasına uygun bir geçiş yaratılmıştır. TÜSİAD, 1980 öncesi birçok raporunda IMF politikalarının uygulanması ile ilgili gerekliliğe değinmektedir. Hükümet tarafından yapılacak ekonomi programlarının IMF tarafından onaylanmasının gerekliliği, her fırsatta vurgulanmaktadır. IMF programındaki özelleştirme ve para politikalarından sapmalarda hükümete uyarılar yapılmaktadır (Milliyet Gazetesi, Die Welt: IMF, 1979; Milliyet Gazetesi, 5.2 Milyar Dolar, 1977).

En nihayetinde askeri müdahalenin ardından TÜSİAD tarafından ve üyelerinin kendi adına yaptıkları açıklamalarda askeri müdahalenin ekonomi için olumlu bir dönem başlattığı ifade edilmiştir. TÜSİAD Başkanı Ali Koçman ülkelerin sahip oldukları rejimin dış ticaretleri üzerinde etkili olmadığını söyleyerek askeri yönetimin ihracat için bir olumsuzluk olmadığını bildirmektedir (Cumhuriyet Gazetesi Arşivi, Koçman: 24 Ocak Kararları, 1981). American Banker gazetesine yapılan benzer bir açıllamada Rahmi Koç, “Türkiye'de ümit verici bir manzara geliştiğini belirterek, memleketin can ve mal emniyetinin teessüs ettiğini” hatırlatmıştır (Milliyet Gazetesi, "Rahmi Koç: Ümit Verici, 1981). Koç, “12 Eylül'den sonra halka büyük ferahlık geldiğini” başka platformlarda da ifade etmektedir (Milliyet Gazetesi, Koç Topluluğu, 1982). 1982 yılında Danimarka Televizyonuna verdiği bir röportajda 12 Eylül askeri darbeyi iş dünyası açısından değerlendirmesi istenmesi üzerine Rahmi Koç şu cevabı vermektedir; “12 Eylül Harekatı'ndan önce her şey güç ve uzun zaman içinde gerçekleştirilebiliyor, her şeye politik açıdan bakılıyordu. Askeri yönetim altında çok hızlı hareket edilebiliyor ve üstelik askeri yönetim yanlış yapsa bile bunu kısa sürede düzeltebiliyor. En önemlisi ise tüm bu işlemler yapılırken politik yaklaşımlar söz konusu olmuyor. Çünkü askeri yönetimin parlamentoda sandalye kaybı ya da seçmen kaybı diye bir kaygısı yok (Milliyet Gazetesi, Rahmi Koç: Düşük Teknoloji, 1982)”. Diğer bir deyişle, TÜSİAD için darbe sonrasında oluşturulan şartlar olumlu olarak değerlendirilmiştir.

Darbe sonrasında sermaye kesimini memnun edecek kararlar alınması yönünde adımlar gelse de zamanla bazı ekonomik düzenlemeler konusunda hükümet ve TÜSİAD’ın karşı karşıya geldiği görülmektedir. Örneğin, 1982 y1lında dönemin başbakan yardımcısı olan Turgut Özal iş dünyasının ekonomi 
ile ilgili yüksek faiz ve düşük enflasyona karşı rahatsızlığı hissettiğini belirterek "açıkça söylenmeyen şikayetlerin altında enflasyonun düşmesi yatmaktadır” açıklamasını yapmaktadır (Milliyet Gazetesi, “Özal İş çevrelerinin eleştirilerini”, 1982). Bu durum, 1980 yılı sonrasında şartların nispeten sermaye kesimi için olumlu şekilde değiştiğini ancak tam olarak iş dünyasını tatmin edecek sonuçları vermediğine işaret etmektedir. Bu nedenle hükümete olan baskılar devam etmektedir. 1983 yılı itibariyle TÜSİAD'ın ekonomiye yönelik endişe ve talepleri basına ve kendi raporlarına yansımaya başlamıştır. Seçimler öncesinde ithalat oranında artışın yanında ihracattaki yavaşlama, kamu-özel sektör yatırımlarındaki dengesizlikler, dışa açık bir ekonomiye geçişte şeffaf bir planlama ihtiyacı (TÜSİAD, 1984 yılına girerken Türk Ekonomisi, 5), artan faiz oranları ve bankacılık sistemi için ihtiyaç duyulan düzenlemeler temel endişeler olarak TÜSİAD tarafından vurgulanmaktadır (Şekil 3).(Milliyet Gazetesi, “İş adamları ekonomideki son”, 1983; Milliyet Gazetesi, “Koçman: Hükümetin yüzde ”, 1983).

Şekil 3. 1983 Yılı İtibariyle TÜSİAD’ın Endişe ve Talepleri

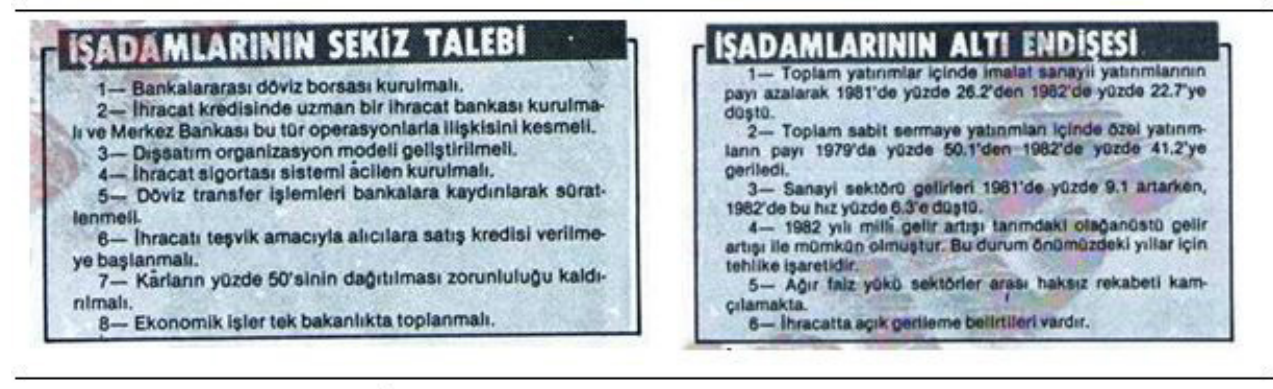

Kaynak: (Milliyet Gazetesi, İş adamları ekonomideki son, 1983)

1983 seçimleri öncesinde Milliyetçi Demokrasi Partisi-Halkçı Parti formülünü destekleyen TÜSİAD, ANAP'ın seçimden tek parti olarak çıkmasının ardından bu parti ile zaman zaman sorunlar yaşamıştır. Özellikle, örgüt içinde değişim talebini daha çok öne çıkarma taraftarı olan TÜSİAD’ın genç liderleri döneminde (1987-1999), siyasal alanla çatışmalar görünür hale gelmiştir. Özal'ın izlediği serbestleşme politikaları ve hükümetin, sanayicilerden daha çok ihracatçıları desteklemesi ihracatçılar ve sanayiciler arasında çatışmaya yol açtı (Güzelsarı ve Aydın 2010:57; Milliyet Gazetesi, "Ekonomik kararları eleştiren sanayiciler”, 1984). Türkiye’nin 1980’lerin başındaki ve sonundaki dış ticareti karşılaştırıldığında bu alanda önemli adımların atıldığını söylemek mümkündür. Bu süreçte sanayiden çok ihracatı geliştirmeye yönelik olan ekonomi politikaları benimsenmiştir. Özellikle devalüasyon ile birlikte ihracat 1988 yılına kadar GSMH içinde payı artan bir eğilim göstermiştir 
(Uzay, 2002: 183). İthalatın ihracat tarafından karşılanma oranı 1980’li yıllar boyunca artmış, ithalat rejimi, gümrük vergisi dışındaki engellerin çoğunun kaldırılması ve gümrük vergilerinin özellikle Ağustos 1989 kararlarından sonra önemli oranda azaltılmasıyla, büyük ölçüde serbestleşmiştir (Buğra, 2013:214). Ayrıca, TÜSİAD’a göre ANAP dönemi ekonomik politikaları büyüme ve istihdam ile ilgili olumlu gelişmeler sağlarken yüksek enflasyon kontrol altına alınamamıştır. Ayrıca, ekonomide tekrar devlet yatırımlarına ağırlık verilmeye başlanması hükümet ve TÜSİAD arasında ortaya çıkan diğer bir ayrılma noktası olmuştur (Güzelsarı ve Aydın 2010: 57). TÜSİAD’ın 1980'li yılların sonunda ve 1990'lı yıllarda ekonomi politikalarının yarattığını ifade ettiği belirsizlik ile ilgili eleştirileri gerek raporlar gerekse basına yapılan açıklamalar ile kamuoyuna yansımıştır.

\section{28 Şubat 1997 Askeri Müdahalesinde TÜSIAD'ın Tutumu}

1980'ler boyunca TÜSİAD’ın ve üyelerinin kendi adına yaptıkları açıllamalar daha çok ikameci bir ekonomiyi terketme, yabancı sermayeyi ülkeye çekme, KİT'lerin yarattığı sorunlar, sosyal güvence sistemi, enflasyon, ihracat-ithalat rejimi ve özelleştirme gibi konulardadır (Milliyet Gazetesi, Die Welt: IMF, 1979; TÜSİAD, 1981; Cumhuriyet Gazetesi, TÜSİAD Başkanı Ali Koçman, 1981; Cumhuriyet Gazetesi, TÜSİAD Başkanı: Özel Sektör, 1981; Cumhuriyet Gazetesi, Ekonomide Diyalog, 1981; Milliyet Gazetesi, Rahmi Koç: En Avantajlı, 1981; Milliyet Gazetesi, İngiliz TV'sinde Konuşan Sabanc1, 1981; Milliyet Gazetesi, Kaşıkçı, 1983; Milliyet Gazetesi, Sabanc1, 1983).

1970’li yılların sonu ve daha çok 1980'li yıllarda ise TÜSİAD’ın hükümetler ile olan ilişkisi ekonomi politikasını liberalleştirmeye yöneliktir. Diğer yandan, Türkiye'de serbest piyasa ekonomisi fikrinin yerleşmesinden sonra ise istikrarlı bir ekonominin ancak istikrarlı bir sosyopolitik ortamda gerçekleşebileceği fikri genel anlayış olarak benimsenmiştir. 1980 yılından sonra küçülen bir kamu sektörüne karşı büyüme ivmesi yakalamış olan özel sektör yatırımları 1991 yılından 1997 yılına kadar devamlı olarak artmış ve GSYH içerisindeki payı yüzde 20,3 seviyelerine kadar gelmiştir (Kalem:2015: 50). Gün geçtikçe büyüyen ve ekonomik gücü arkasına alan bu kuruluş, sadece ekonomi ile kendisini sınırlı görmemiş, ülke siyasetinde de söz söyler duruma gelmiştir. Fakat, 1980'li yıllarda Türkiye'de serbest ekonomi dönemi ile birçok ekonomik göstergede bozulmayı da beraberinde getirmiştir (Kalem, 2015: 49). Bu nedenle TÜSİAD ekonomi politikalarını eleştirmeye devam etmiştir. Ekonominin nasıl olması gerektiği ile ilgili baskısını artıran TÜSİAD, aynı zamanda siyasi ve sosyal bir takım konularda da kanaat belirtmeye başlamıştır (Gündem, 2004). 
Tablo 1. 1976-1987 Yllları Ekonomik Göstergeleri

\begin{tabular}{|c|c|c|c|}
\hline Yıllar & $\begin{array}{c}\text { Net Milli Gelir } \\
\text { (ABD\$) }\end{array}$ & GSMH (ABD\$) & $\begin{array}{c}\text { Y1llık Tüketici } \\
\text { Fiyatları Enflasyon } \\
\text { Oranı (\%) }\end{array}$ \\
\hline 1976 & 43.633 .161 .295 & 51.280 .134 .554 & 17,5 \\
\hline 1977 & 50.017 .974 .949 & 58.676 .813 .687 & 26,0 \\
\hline 1978 & 55.496 .920 .245 & 65.147 .022 .486 & 61,9 \\
\hline 1979 & 75.589 .425 .921 & 89.394 .085 .658 & 63,5 \\
\hline 1980 & 57.715 .563 .567 & 68.789 .289 .566 & 94,3 \\
\hline 1981 & 59.394 .924 .671 & 71.040 .020 .140 & 37,6 \\
\hline 1982 & 53.884 .257 .746 & 64.546 .332 .581 & 29,1 \\
\hline 1983 & 51.452 .168 .351 & 61.678 .280 .115 & 31,4 \\
\hline 1984 & 49.968 .600 .101 & 59.989 .909 .458 & 48,4 \\
\hline 1986 & 63.217 .744 .549 & 75.728 .009 .963 & 34,6 \\
\hline 1987 & 71.481 .102 .436 & 87.172 .789 .528 & 38,9 \\
\hline
\end{tabular}

Kaynak: Data Bank, World Development Indicators, https://databank.worldbank.org/source/world-development-indicators\#selectedDimension_WDI_Ctry, Erişim Tarihi: 05.12.2020.

1990’lı yıllarda TÜSİAD, ekonomik sorunların ötesinde Türkiye'nin diğer sorunları ile ilgili tavsiyelerde bulunmaya başlamıştır (Buyuktanir, 2018). Böylece, insan hakları ve demokratik değerlerin ülkede yerleşmesi konusundaki hassasiyetler de dile getirilmeye başlanmıştır. İstikrarlı bir siyasi ortamın önemli olduğu üzerinde duran TÜSİAD, böyle bir siyasi istikrarı güçlü idarelerin sağlayabileceğini düşündükleri için "politika ve demokrasi” konuları ile ilgilendiklerini ifade etmektedir (Milliyet Gazetesi, Erken Seçim Değil, 1997). Bu çerçevede farklı zamanlarda hazırlatılan raporlar ve süreli yayınlar aracılığıyla TÜSİAD, siyasi meselelere yaklaşımlarını ortaya koymuştur (Dilaveroğlu, 2012:59). 28 Şubat sürecinde önemli bir olay olarak değerlendirilen TÜSİAD Demokratikleşme Perspektifleri raporunun temeli olarak ifade edilmektedir (Cumhuriyet Gazetesi, TÜSİAD Başkanı Muharrem Kaya, 1997). Buğra (2013:195) tarafından da vurgulandığı gibi 1960’larda ve 1970’lerde özel sektörün alanının net bir şekilde belirlenmesi üzerinde duran Türkiye işadamları, TÜSİAD’ın 28 Şubat sürecinde gözlemlendiği üzere, siyasal olarak da etkili olma yönünde çaba göstermeye başlamışlardır.

1990'larda TÜSİAD hem ekonomik hem de toplumsal konulardaki düzenlemeler konusunda etkisini artırma çabaları hükümetler ile çatışmalar 
yaşamasına da neden olmuştur. Bu çatışmalar, bazı dönemlerde hükümetlerin büyük sanayicilere birtakım kısıtlamalar getirmelerine neden olmuştur. Örneğin, ANAP iktidarının sona erdiği 1991 seçimlerinin sonunda DYP-SHP tarafından oluşturulan koalisyon hükümeti ile TÜSİAD'ın ilişkileri ilk altı ay nispeten olumlu geçmiştir. Bu süreçte ekonomik programın oluşturulmasında TÜSİAD ile işbirliğine gidilmiştir. Sonrasında ise TÜSİAD’ın Cumhurbaşkanı Turgut Özal'a karşı hükümetin istediği tavrı almaması ilişkilerin gerilmesine neden olmuştur. Bu dönemde hükümet büyük sanayicilerin aleyhine bir vergi yasa tasarısını Meclise sevk etmiştir. Bu durum büyük sanayicileri o kadar rahatsız etmiştir ki Vehbi Koç bizzat Başbakan Çiller'e mektup yazarak yasa tasarısının yumuşatılmasını talep etmiştir (Alkan,1998: 334, 335).

Türk ekonomisinin 1994 yılında yaşadığı krizden çıkması için Uluslararası Para Fonu (IMF-International Money Fund) tarafından da desteklenen 5 Nisan İstikrar Programı olarak bilinen önlemlere başvurulmuştur. Bu kararlarla; enflasyonun düşürmek, dış ticaret gelirlerini artırmak için bazı döviz politikaları benimsenmiş ve bu dönemde cari fazla oluşmuştur. Diğer yandan, artan faiz ve döviz nedeniyle işletmelerin maliyetlerinde artışlar meydana gelmiştir. Ekonominin giderek belirsiz şartlar yaratması üzerine özel sektörden tepkiler gelmeye başlamıştır. Oluşan belirsiz şartlara karşı TÜSİAD doğal olarak tepki vermekte, devlet tarafından konulan vergileri, döviz ve para basma politikasını eleştirmektedir Belirsizlik ile ilgili oluşan rahatsılık TÜSİAD genel kurullarında da dile getirilmektedir. 1994 yılında yapılan 24.Genel Kurulda ekonominin politik kaygılar nedeni ile ikinci plana atıldığı belirtilmiştir (Milliyet Gazetesi, Çiller Topa Tutuldu, 1994).

1990’lı yıllarda TÜSİAD’ın eleştirileri hükümet yetkilileri ile çatışma şekline dönüştüğü görülmektedir. Bu durum, dönemin TÜSİAD başkanı Komili'nin "uyarı yapanı hain ilan etmekle ekonomi düzelmez" sözlerinden de anlaşılmaktadır (Milliyet Gazetesi, Çiller Topa Tutuldu, 1994)”. Özellikle Tansu Çiller döneminde TÜSİAD yönetimi ile DYP arasındaki ilişkiler iyice kapalı bir görünüm kazanmış ve bu sürece paralel olarak TÜSİAD’ın giderek dışlanma eğilimi ortaya çıkmıştır (Alkan, 1998). Buna karşın TÜSİAD'ın 1990'lı yılların ortasında devleti yönetenlerin görmezden gelemeyecekleri kadar önemli bir güç unsuru olduğu anlaşılmaktadır. Hatta, görülüyor ki TÜSİAD, hükümete daha çok baskı yapabilen bir kuruluş haline gelmiştir. Örneğin, 1994 yılında TÜSİAD ile bir araya gelen Başbakan Çiller, "Bana karşı büyük bir güven bunalımı var. Ama aslında ekonomik durum o kadar da vahim değil. Ne yapmalıyım ki, size karşı bu güveni yeniden sağlayayım?” demekte, TÜSİAD ile anlaşma yollarını aramaktadır (Milliyet Gazetesi, Bana Güvenmeniz İçin, 1994). Aynı şekilde, 1994 yılında dönemin Başbakanı Tansu Çiller 
ile istişare toplantısı sonunda Halis Komili kendileri tarafından yapılan uyarıların hükümet tarafından "yavaş yavaş” dikkate alınmaya başladığını belirtmektedir. Başbakan Çiller’in TÜSİAD ile "karşılıklı güvenin tesis edildiği" sözleri TÜSİAD’ın bir etki unsuru olarak gücünü teyit etmektedir (Cumhuriyet Gazetesi, Çiller TÜSİAD ile Uzlaşıyor, 1994).

TÜSİAD yaşanan ekonomik ve sosyal problemlerin çözümünün ekonominin dışa açılması sürecinde Avrupa Birliği ile entegrasyon ile başarılabileceğini savunmaktadır. Avrupa Birliği ile entegre olmak ise sadece ekonomik değil aynı zamanda sosyal anlamda da birtakım değişiklikleri zorunlu kılmaktadır. $\mathrm{Bu}$ zorunluluğu gören TÜSİAD, sadece ekonomik değil aynı zamanda diğer alanlardaki düzenlemeleri yapabilecek hükümetlere daha olumlu bakış açısına sahiptir. 1990'lı yıllarda Türkiye'nin Gümrük Birliğine üye olabilmesi TÜSİAD’ın gündemindeki en önemli konuların başında gelmektedir. Nitekim, 1994 yılındaki yerel seçimlerde gümrük birliği fikrine mesafeli olan Refah Partisinin yükselişi TÜSİAD için beklenmedik bir durum olarak ortaya çlkmıştır. 1995 seçimleri öncesindeki dönemde TÜSİAD, Avrupa ile entegrasyon vurgusunu örgüt stratejisinin merkezine oturtmuştur. 1997 yllında başkan olan Muharrem Kayhan, TÜSİAD’ın o dönemki hükümete karşı tutum takınmasının nedenlerinden birisi olan $\mathrm{AB} /$ Gümrük Birliği entegrasyonuna siyasi iradenin bakış açısını şu şekilde ifade etmektedir: “TÜSİAD'ın eleştirel bir tutum takınması özellikle şu yönden oldu: Özelleştirmelere karşı bir ekonomik tutum sergilendi, Gümrük Birliğine karşı "Yeniden gözden geçirelim." diye bir tutum sergilendi yani TÜSİAD'ın ekonomik olarak eleştirel bakması hep bu çerçevededir (TBMM, 2012)". Buna paralel olarak, Türk-Yunan ilişkileri dahil olmak üzere, uyumun gerektirdiği siyasal reformlar, anayasa değişiklikleri ve insan hakları ile ilgili düzenlemeleri kapsayan girişim ve etkinliklere ağırlık verilmeye başlanmıştır (Alkan, 1998:337). 1995 yılında yapılan yüksek istişare kurulundaki değerlendirmelerden kamuoyuna yansıyan sonuçlar; vergi, sosyal güvenlik, KİT reformlarının yapılması ve küçük-orta boy işletmeleri destekleyici programlar gibi iş dünyasını ilgilendiren konular olmakla birlikte seçim yasası, düşünce ve ifade özgürlüğü, güçlü bir yerinden yönetim, şeffaf devlet ve bürokrasi gibi siyasal alanda, devletin işleyişine dair kanaatleri de kapsamaktadır (Milliyet Gazetesi, Demokrasi İstikrar 1995; Milliyet Gazetesi, TÜSİAD’dan Çağrı, 1995). Öyle ki, 1995’te TÜSİAD şeref başkanı olan Rahmi Koç, Türkiye'nin dış ilişkilere önem vermesini ve Kıbrıs sorununu biran önce çözmesi gerektiğini belirtmektedir (Milliyet Gazetesi , Siyasi Çözüm İçin Üç Şart, 1995). Diğer yandan, TÜSİAD'ın bu denli siyasallaşmasına hükümet tarafından bir takım tepkiler gelmektedir. Bu dönemde, hükümet yetkilileri TÜSİAD’ı siyasi konulara karışmaması için uyarmaktadır. Örneğin, Doğruyol ve SHP koalisyon hükümetinin 
sözcüsü olan Yıldırım Aktuna, TÜSİAD’a yönelik olarak "ekonomik konudaki düşüncelerini ortaya koyabilirler, ama bıraksınlar siyaseti bizler yapalım” şeklinde tepkiyi dile getirmektedir (Milliyet Gazetesi, Aktuna, 1995).

1996 yılında kurulan Refahyol Hükümeti ve işadamları arasındaki çekişme ekonomi politikaları konusundaki anlayışların çelişmesinden kaynaklanmıştır. İlk evredeki çekişmeler; hükümetin ekonomi politikası uygulamalarından ve bu politikalardan işadamlarının duyduğu kaygılardan beslenmiştir. Temel olarak otomotiv sektörünü ilgilendiren bedelsiz ithalat kararı, denk bütçe uygulaması, kaynak paketleri, AB'ye karşı soğuk tutum, özelleştirme ve KOBİ önceliği ile ilgili konular öncelikli başlıklar olmuştur (Alkan 1998:340). TÜSİAD, Refahyol tarafından ekonomiyi iyileştirmek için benimdediği kaynak paketlerini eleştirmektedir. Bu paketlere, ekonomi için kalıcı çözümler yaratamayacağı düşüncesi ile karşı çıkılmaktadır (TÜSİAD, 1997:13). Bu dönemde TÜSİAD, Birinci Kaynak Paketinde yer alan bedelsiz ithalat ile ilgili düzenlemenin özellikle otomotiv sektörü ve makine sanayisine vereceği zararlar üzerinde durmaktadır (Cumhuriyet Gazetesi, TÜSİAD’dan Kriz Uyarısı, 1996). Türk vatandaşlarının Ziraat Bankası nezdinde 50 bin marklık bir yıl vadeli yüzde on faizli döviz hesabı açmaları halinde, Türkiye'ye bedelsiz olarak kullanılmış veya sıfır kilometre otomobil, makine, teçhizat ve benzeri yatırım malları getirebilmelerine izin veren kararnameye TÜSİAD, olumlu bakmamaktadır. Özellikle otomotiv sektöründe önemli yatırımları olan Koç grubu, hükümeti kararname konusunda yoğun bir şekilde eleştirmiştir. Bu eleştirilere rağmen, hükümet yabancı otomotiv yatırımcılarının yatırımlarını teşvik eden bir kararname daha çıkarmıştır. Hyundai, Toyota, Honda ve Renault firmalarını kapsayan kararname Koç Grubu'na ait olan Tofaş ve Otosan’ı dışarda bırakmıştır. Böylece, yukarıda adı geçen yabancı firmalara vergi avantajı ile yatırım yapma imkânı ve ar-ge yatırımlarında uygun faiz oranları ile kredi imkanları sunuluyordu (Alkan, 1998:341,342). Bu örnekten de anlaşıldığı üzere dönemin hükümeti ve TÜSİAD karşılıklı bir güç savaşı içine girmişlerdir.

TÜSİAD’ın Refahyol dönemindeki endişelerinden birisi de özelleştirme politikası ile ilgilidir. Daha önce de ifade edildiği gibi TÜSİAD’ın gündeminde her zaman özelleştirme vardır. Diğer yandan, Refahyol hükümetinin özelleştirme politikasının TÜSİAD’ı endişelendirildiği belirtilmektedir. Özelleştirmeler ile daha çok Anadolu sermayesini temsil eden MÜSİAD (Müstakil Sanayici ve İşadamları Derneği) içerisinden büyük sermaye grubunun oluşturulması ile ilgili gelişmelerin olabileceği düşünülmektedir. Hükümetin, MÜSİAD’ın da desteği ile büyük sanayicilerden çok KOBİ ekseninde ekonomiyi güçlendirmeyi amaçlamaktadır. 1996 yılında çıkarılan kararname ile KOBİ’lere vergi ve yatırım indirimleri gibi bazı destekler sağlanmıştır. $\mathrm{Bu}$ 
durum, muhafazakâr Anadolu sermayesinin güçlendirildiği ve yeni bir sermaye ekseninin yaratıldığı şeklinde yorumlanmaktadır (Alkan, 1998:344).

1996 yılında iktidar olan Refahyol'un ekonomi politikaları TÜSİAD tarafından yoğun olarak eleştirilmiştir (Cumhuriyet Gazetesi, TÜSİAD Başkanı Refahyol'un, 1996). Refahyol Hükümeti'nin AB'ye giriş ile ilgili çabalarının önceki hükümetlere göre azalmış olması da TUSİAD için bir olumsuzluk teşkil etmiştir. TÜSİAD, AB üyelik süreci ve Gümrük Birliği gibi konuları ağırdan aldığını düşündüğü Refahyol koalisyonu hükümetine ekonomik ve siyasal politikalarına karşı tepkilerini dile getirmeye devam etmiştir. 1997 yılında Prof. Dr. Bülent Tanör'e “Türkiye’nin Demokratikleşme Perspektifleri” adlı bir rapor hazırlatılmıştır. Raporda seçim yasası, temel eğitim-öğretim sistemi, milletvekili dokunulmazlığı, azınlık hakları ve düşünce suçuna verilen cezalar ile ilgili öneriler bulunmaktadır. Nitekim raporu hazırlayan Tanör, 1990 başlarından itibaren TÜSİAD'ın ekonomik liberalizmi siyasi liberalizm ile tamamlamak istediğini belirtmektedir (Cumhuriyet Gazetesi, TÜSİAD’ın Tartışma Yaratan, 1997). 2012 yılında darbeleri araştırma komisyonuna konuşan 1997-1998 yılları arasında TÜSİAD’ın Başkanlığını yapmış olan Muharrem Kayhan'ın sözleri kurumun 1990’lı yıllardaki tutumunu ortaya koymaktadır:

"1996 yılının ortasından itibaren TÜSİAD; ekonomik gelişmenin, piyasa ekonomisi gelişmesinin ekonomik çerçevenin dışında, demokratikleşme perspektifinde de daha yeşerebileceğini, daha hızlı gelişebileceğini gördüğü için kendi içinde önemli bir çalışma başlattı. Bu da 1997 yıl1nın 20 Ocağında -yanılmıyorsam Ocak başında yayınlanan- "Türkiye'de Demokratikleşme Perspektifleri” başlığı altında yayınlanan bir rapordu. Bu raporu da TÜSİAD 1997 yılının 20-21 Ocağında, yanılmıyorsam, basına açıkladı. Dolayısıyla bu da bir yerde, bizim "Kopenhag Kriterlerine giden yol” dediğimiz dönemdir. Burada demokratikleşme konusunda, siyasi sistem konusunda, askerin siyasetteki rolü konusunda bireysel hak ve özgürlükler konusunda çok önemli ve o zaman için fevkalade radikal görünen fakat zamanın geçmesiyle beraber, aslında bizim 2002-2004 yılları arasında gerçekleşen uyum paketlerimizin içeriğiyle önemli ölçüde bağdaşan öneriler yaptı".

TÜSİAD, “Türkiye’nin Demokratikleşme Perspektifleri” raporunun öncesinde Refahyol hükümetine ciddi eleştiriler yöneltmektedir. 28 Şubat 1997 öncesinde TÜSİAD başkanı Halis Komili, Refahyol Hükümeti'nin ekonomi, demokrasi ve siyaset konusunda olumlu kararlar almadığını ifade etmektedir (Milliyet Gazetesi, Paket Depremi, 1996). Gümrük Birliği ve Avrupa Birliği’ne entegrasyon politikalarının göz ardı edilmeye başlandığının düşünülmesi TÜSİAD’ın hükümete karşı tavır almasında etkili olmuştur. 
Askeri müdahalelere karşı olduğunu ifade eden TÜSİAD, hükümet değişikliği için demokratik yolların benimsenmesi gerektiğini de belirtmektedir. Diğer yandan, hükümet değişikliği için de bir sivil toplum kuruluşu olarak kamuoyu yaratma konusunda etkili bir biçimde faaliyet göstermiştir. 1979 yılında Ecevit Hükümet’ine karşı yapılan ama planlanan tamamının gerçekleştirilmesine hükümet tarafından izin verilmemiştir. Gazetelere verilen ve hükümeti eleştirilen ilanların tamamı yayınlanamamıştır. Böylece, 1990'lı yıllara kadar TÜSİAD ekonomi politikalarında baskı unsuru olma yönünde söylemlerle kamuoyunda yer almıştır. Başka bir deyişle liberal bir piayasa ve ekonomi anlayışa sahip olan TÜSİAD’ın devletle olan ilişkisi ilk başlarda üyelerinin avantajı için daha çok ekonomi politikalarını etkilemeye yöneliktir. Fakat, 1990’lı yıllar itibariyle bir paradigma değişikliği yaşadığı anlaşılan TÜSİAD'ın siyasi görüş bildiren, bu konuda değişim yaratma konusunda çaba gösteren bir kuruluş haline geldiği görülmektedir.

\section{Sonuç}

TÜSİAD kurulduğu 1971 yılından beri ülkenin en önemli sanayi kuruluşlarını temsil etmektedir. TÜSİAD; kamu sektörünün asgari düzeyde olduğu, yabancı sermayenin desteklendiği ve ihracata yönelik serbest bir ekonominin oluşturulması için mücadele vermiştir. 1970'li yıllarda dünyada küresel bir ekonomik düzenin oluşturulması ile ilgili çabaların arttığı dönemde TÜSİAD yönetimdeki hükümetlere oluşturduğu rapor, görüş ve kamuoyu açıklamaları ile tavsiyelerde bulunmuştur. Bu tavsiyeler özellikle, 1980'li yıllardan önce ağırlıklı olarak ekonomi ile ilgilidir. Bianchi (1984: 268) tarafından da belirtildiği gibi TÜSİAD’ın politik tavrı başlangıçta çok belirgin değildir. TÜSİAD'ın sosyopolitik anlamda etkililiğinin 1990'larda arttığı kabul edilmesine rağmen 1980'lerin başında önce Ecevit Hükümetine karşı takındıkları sosyopolitik tavır dikkat çekmektedir. Liberal politikaların dünyada etkisini artırdığı dönemde 1978 yılında ikinci Ecevit hükümetinin düşürülmesine neden olan süreçte TÜSİAD etkili olmaya çalışmıştır. Bu sürecin sonrasında da TÜSİAD Türkiye'nin serbestleşmesini engellediğini düşündüğü ekonomik anlayışa sahip olan hükümetleri eleştirmeye başlamıştır. Bu anlamda, 12 Eylül 1980 askeri darbesinden önce liberal ekonomiye geçiş ile ilgili raporlar yayınladığ1 ve kamuoyu oluşturmaya çalıştığı görülen TÜSİAD, askeri darbeyi 24 Ocak kararlarının uygulanması için bir firsat olarak yorumlamıştır. Diğer yandan, 1980'lerde TÜSİAD'ın siyasi, sosyo politik konulardaki tavrı nispeten cılız kalmıştır. Bunun nedeni "güç olgusu" ile ifade edilebilir. TÜSİAD, bahsedilen dönemde özel sektör ekonomideki kısıtlı payı ile henüz bir varlığını ispatlama dönemindedir (Cumhuriyet Gazetesi, TÜSİAD Başkanı Muharrem Kaya, 1997). 
Ayrıca, bu dönemde uygulanmaya çalışılan ekonomik politikalar çoğunlukla TÜSİAD’ın savunduğu politikalara paralel niteliktedir.

1990'lı yıllarda sadece ekonomik değil aynı zamanda sosyopolitik konularda da uyarılar yapıldığı ve bu konularda çatışmalar yaşandığı görülmektedir. Nihayet, 1990'yı yıllarda TÜSİAD ekonomik olarak nispeten daha önemli bir güç haline gelmiştir. Bu dönemde hükümetler ekonomik konularda alenen ve sert bir biçimde eleştirildiği gibi aynı zamandan sosyopolitik konularda da TÜSİAD tarafından önemli uyarılar gelmektedir. Yapılan açıklamalar, kamuoyu oluşturma konusunda yurtdışındaki kredilendirme kuruluşları ve askeri mevkilerde bulunan bürokratlar ile yakın ilişkiler kurulduğunu göstermektedir. Diğer bir deyişle, TÜSİAD, 1990’lı ylllarda ekonomik ve politik anlamda önemli bir noktaya gelmiştir. 28 Şubat 1997 askeri darbesine giden süreçte dönemin hükümetler ekonomi politikaları açısından eleştirildiği gibi aynı zamanda sosyal politikalar açısından da görüş farklılıkları yoğun olarak kamuoyu önünde sert bir biçimde ortaya konmuştur. Batı demokrasisine atfedilen değerlerin benimsenmesini aynı zamanda Batıyla ekonomik entegrasyonun ön koşulu olarak kabul eden TÜSİAD bu konudaki yeterli görmediği hükümetlerle mücadele etmiştir. 28 Şubat sürecinde önemli bir olay olarak kabul edilen, Genel Kurmaylığa “demokratikleşme” konusunda verilen rapor ekonomik konulardan çok devlet organizasyonu, demokratik değerler ve haklar konusunu içermektedir.

İş adamı birliklerinin var olmalarının en önemli nedeni çevredeki kaynakları etkin bir şekilde üyelerine yönlendirmesine bağlıdır. Bu kuruluşlar doğal olarak üyelerinin fikirlerini yansıtmaktadır. (Wilson, 1973). Bu anlamda Türkiye'nin çoğunlukla Avrupayla entegre olmak isteyen, seküler çizgide ve libereral bir anlayışı benimsemiş olan üyelerden oluşan TÜSİAD’ın (Buyuktanir, 2018) liberal ekonominin oluşması için mücadele etmesi beklenen bir sonuç olarak ortaya çıkmaktadır. Nitekim TÜSİAD ekonominin şekillenmesi sürecinde 1970'lerin sonundan itibaren etkili olmayı denemişse de esasen 1980 darbesinden sonra oluşan ekonomik serbestleşme döneminde ekonomik ve dolayısıyla siyasi gücünü önemli oranda artırmıştır (Kutlay, 2019). Bir sivil toplum kuruluşu olsa da TÜSİAD’ın en nihayetinde iş adamlarından oluşan bir grup olarak piyasanın işleyiş şeklini belirleyen devlet organlarını etkileme gücüne ulaşmış olması oldukça önemlidir. Bu güç ile birlikte 1990'lı yıllarda batıya entegre olmuş bir liberal ekonominin oluşması önünde engel olarak gördüğü hükümetleri siyasi anlamda da etkili biçimde eleştirmeye başlamıştır. Batı ekonomisine entegrasyona engel olabilecek anlayışların yerleşmesine karşı tavır takınarak kendisi ve üyeleri için faaliyet alanını genişletmiştir. Dış ticaretin \%80'ini gerçekleştiren üyelerden oluşan TÜSİAD’ın 
bu konudaki motivasyonunu anlamak mümkündür. İş adamları kurmuş oldukları bu yapı ile sahip oldukları kaynakları korumak, garantiye almak ve gelecekte bu kaynakları geliştirmek için siyasi bir güç olma konusunda da adımlar atmaktan çekinmemiştir.

\section{Kaynakça}

Alkan, Haluk (1998), Türkiye'de Baskı Grupları: Siyaset ve Işadamı Örgütlenmeleri (Odalar, Tüsiad, Müsiad), Yayınlanmamış Doktora Tezi. İstanbul : Marmara Üniversitesi Sosyal Bilimler Anabilim Dalı .

Bianchi, Robert (1984), Interest Groups and Political Development in Turkey. Princeton: Princeton University Press.

Buğra, Ayşe (2013). Devlet ve Işadamları. İstanbul: İletişim Yayınları.

Buyuktanir Karacan, Derya. «Public Diplomacy Activities of TÜSIAD and MÜSIAD During the AK Party Era.» Gazi Akademik Bakış 11, no. 23 (2018): 73-98.

Cumhuriyet Gazetesi (1981), “Koçman: 24 Ocak Kararları ihracatı Artırmadı”, 07 Ocak 1981.

Cumhuriyet Gazetesi (1981), “TÜSIAD Başkanı Ali Koçman: 24 Ocak Kararlarını Sonuna Kadar Savunacağız”, 01 Ocak 1981.

Cumhuriyet Gazetesi (1981), “TÜSIAD Başkanı: Özel Sektör En Parlak Dönemini 1965-1971 Arasından Yaşadı”, 23 Mayıs 1981. (1981, 05 23).

Cumhuriyet Gazetesi (1981), “Ekonomide Diyalog”, 14 Haziran 1981.

Cumhuriyet Gazetesi (1982), "12 Eylül Askeri Harekatı Olmasaydı 24 Ocak Kararları Başarıya Ulaşamazdı”, 26 Ocak 1982.

Cumhuriyet Gazetesi (1994), “Çiller TÜSiAD ile Uzlaşıyor”, 12 Şubat 1994.

Cumhuriyet Gazetesi (1996), “TÜSIAD Başkanı Refahyol'un Ekonomi Politikalarını Eleştirdi: Ekonomi Uçurumun Kenarında”, 16 Mayıs 1996.

Cumhuriyet Gazetesi (1996), “TÜSIAD’dan Kriz Uyarısı”, 09. Eylül 1996.

Cumhuriyet Gazetesi (1997), “TÜSIAD’ın Tartışma Yaratan Raporunu Hazırlayan Prof.Dr. Bülent Tanör'le Raporu Konuştuk”, 16 Ocak 1997.

Cumhuriyet Gazetesi (1997), “TÜSIAD Başkanı Muharrem Kaya: Biz de Evrim Geçiriyoruz” 26 Ocak 1997.

Dilaveroğlu, Ergün (2012), "28 Şubat Süreci ve Bir Sivil Toplum Kuruluşu Olarak Tüsiad'ın Sürece Bakış". Sakarya iktisat Dergisi, 1(3), 59-74.

Durmuş, Mustafa (2011), "12 Eylül Askeri Darbesinin Ekonomi Politiği”. Memleket Siyaset Yönetim, 6(15), 95-138.

Düzgün, Eren «The Political Economy of the Transition to Capitalism in the Ottoman Empire and Turkey: Towards a New Interpretation.» Case Studies in the Origins of Capitalism içinde, yazan Charles Post Xavier Lafrance, 265-290. Cham: Palgrave Macmillan, 2019.

Gündem, Şebnem, The NGOs As Policy Actors: The Case of TÜSIAD With Regard to Turkey's EU Membership. Yayınlanmamış Y.Lisans Tezi, Ankara: Ortadoğu Teknik Üniversitesi, 2004.

Kalem, Ali (2015), Türkiye'deki Kamu Yatırımlarının Özel Sektör Yatırımlarına Etkisinin Incelenmesi (Uzmanlık Tezi). Ankara: T.C. Kalkınma Bakanlığı . 
Kluge, Pascal (2009), "TÜSIAD and the Armenian-Turkish Relations:Turkish Economy between Progress and National Identity". Iran and the Caucasus(13), 341-356.

Komili, Halis (1994, Mart), “Sağlam Senaryo İyi Yönetmen”. Görüş, s. 14-15.

Koyuncu, Berrin (2006), “Küreselleşme ve Türk İşadamları Derneği: TÜSiAD Örneği”. Uluslararası ilişkiler, 3(9), 125-149.

Kutlay, Mustafa, The Political Economies of Turkey and Greece: Crisis and Change. Cham: Palgrave Macmillan, 2019.

Milliyet Gazetesi (1977), “5.2 Milyar Dolar Döviz Gerekecek”, 12 Ağustos 1977.

Milliyet Gazetesi (1979), “Berker: Bildirimizin siyasal bir amacı yok”, 16 Mayıs 1979.

Milliyet Gazetesi (1979), “Die Welt: IMF, Türk Lirasının Devalüasyonu Koşulundan Vazgeçmişe Benziyor", 19 Mayıs 1979.

Milliyet Gazetesi (1981), “İngiliz TV'sinde Konuşan Sabancı ‘Hayal Sanılan İşleri Başardık Korkmuyoruz' dedi”, 14 Nisan 1981.

Milliyet Gazetesi (1981), “Rahmi Koç: En Avantajı Ne İse O Üretilmelidir”, 24 Ekim 1981.

Milliyet Gazetesi (1982), “Rahmi Koç: Düşük Teknoloji, Zayıf Örgüt, Kötü Kalitenin Sonu Gelmiştir”, 26 Ocak 1982.

Milliyet Gazetesi (1981), “Rahmi Koç: Ümit Verici Bir Ekonomik Manzara Gelişiyor”, 18 Aralık 1981.

Milliyet Gazetesi (1982), "Özal İş çevrelerinin eleştirilerini cevaplandırdı: Türk mucizesi 1982'de başarılacaktır”, 23 Ocak 1982.

Milliyet Gazetesi (1983), "iş̧ adamları ekonomideki son gelişmelerden endişeli. TÜSIAD: Hızlı çalışan bir ekonomi ve mali yönetim modeli geliştirilmeli”, 07 Mayıs 1983.

Milliyet Gazetesi (1983), "Koçman: Hükümetin yüzde 20 enflasyon tahmini gerçekçi değil”, 14. Ağustos 1983.

Milliyet Gazetesi (1984), “Ekonomik kararları eleştiren Sanayiciler: Kısa sürede çökeriz”, 27 Ocak 1984.

Milliyet Gazetesi (1982), “Koç Topluluğu 24 Milyon Lira Bağışladı”, 18 Aralık 1982.

Milliyet Gazetesi (1983), "Sabancı: Türkiye Bir Alıştırma Döneminden Geçmeli”, 05. Ağustos 1983.

Milliyet Gazetesi (1983), “Kaşıkçı: Türkiye Yatırım İçin İyi Bir Ülke Olabilir”, 12. Ekim 1983.

Milliyet Gazetesi (1994), “Çiller Topa Tutuldu”, 21 Ocak 1994.

Milliyet Gazetesi (1994), “Bana Güvenmeniz İçin Ne Yapabilirim?” 12 Şubat 1994.

Milliyet Gazetesi (1995), “Siyasi Çözüm İçin Üç Şart”, 20 Ocak 1995.

Milliyet Gazetesi (1995), "Aktuna: Bırakın Siyaseti Biz Yapalım. 21 Ocak 1995.

Milliyet Gazetesi (1995), “Demokrasi İstikrar ve ANAYOL”, 09 Aralık 1995.

Milliyet Gazetesi (1995), “TÜSIAD’dan Çağrı”, 09 Aralık 1995.

Milliyet Gazetesi (1996), “Paket Depremi”, 21. Haziran 1996.

Milliyet Gazetesi (1997), “Erken Seçim Değil Yeni Hükümet”, 12 Mayıs 1997.

Sönmez, Mustafa (1992), Türkiye’de Holdingler: Kırk Haramiler. Ankara: Arkadaş Yayınevi.

Tatlıyer, Mevlüt (2017, 02), 28 Şubat Ekonomisi. Mevlüt Tatlıyer: https://mevluttatliyer. weebly.com/uploads/6/2/6/8/62684825/mevl\%C3\%BCt_tat|\%C4\%B1yer_-_28_\%C5\%9Eubat_ekonomisi.pdf adresinden alınmıştır. 
TBMM, Darbeleri Araştırma Komisyonu. (2012). Darbeleri Araştırma Komisyonu, 28 Şubat, Muharrem Kayhan. TBMM: https:/www.tbmm.gov.tr/arastirma_komisyonlari/ darbe_muhtira/docs/tutanak_son/28_subat_alt_komisyonu/28_subat_alt_komisyonu/09.10.2012/Muharrem\%2OKayhan-09.10.2012.pdf, (E.T. 05 Ağustos 2019).

TÜSİAD (1977) 1977 Yılına Girerken Türk Ekonomisi. İstanbul: TÜSIAD.

TÜSIAD (1979), 1979 Gazete ilanları, https//tusiad.org/tr/tum/item/9376-tusiad-1979-gazete-ilanlari; (E.T. 03 Aralık 2020).

TÜSIAD (1980) 1980 Yılına Girerken Türk Ekonomisi. İstanbul: TÜSIAD.

TÜSIAD (1981) 1981 Yılına Girerken Türk Ekonomisi . İstanbul: TÜSIAD.

TÜSIAD (1997) 1997 Yılına Girerken Türk Ekonomisi. İstanbul: TÜSIAD.

Wilson, James Q., Political Organizations. NY: Basic, 1973.

World Data Bank (2020), World Development Indicators, https://databank.worldbank.org/ source/world-development indicators\#selectedDimension_WDI_Ctry, (E.T. 05 Aralık 2020). 